\title{
Microbial inoculants and Trichoderma viride consortia for growth promotion and disease management in ginger
}

\author{
T R Haritha \& K S Gopal* \\ Department of Agricultural Microbiology, College of Agriculture, \\ Kerala Agricultural University, Vellanikkara-680 656, Thrissur, Kerala. \\ *E-mail:ks.gopal@kau.in
}

Received 02 February 2021; Revised 06 May 2021; Accepted 01 June 2021

\begin{abstract}
A study was conducted to evaluate the effect of microbial inoculants consortia on ginger under field conditions. Three biofertilizers comprising of Azospirillum lipoferum (nitrogen fixer KAUAZO), Bacillus megaterium (phosphate solubilizer KAU-PSB), Bacillus sporothermodurans (potash solubilizer KAU-KSB) and two biocontrol agents namely, Pseudomonas fluorescens (KAU-PF) and Trichoderma viride (KAU-TV) were used in the study. Compatibility studies revealed that all the isolates were compatible with each other. However, P. fluorescens and T. viride were incompatible with each other under in vitro. Under field evaluation, consortia of microbial inoculants performed better than the single inoculants in terms of yield and disease management. The organic Adhoc package recorded the minimum incidence of rhizome rot $(2.09 \%)$ among all the treatments. However, KAU-AZO + KAU-PSB + KAU-KSB + KAU-TV recorded the minimum rhizome rot $(5.23 \%)$ incidence among the consortia. In the case of Rhizoctonia leaf blight disease, consortia of KAU-AZO + KAU-PSB + KAU-KSB + KAU-PF showed the minimum incidence (5.21\%). In general, consortium of A. lipoferum, B. megaterium (PSB), B. sporothermodurans (KSB) and T. viride was the most efficient for plant growth promotion and disease management in ginger.
\end{abstract}

Keywords: compatibility, consortia, disease management, field conditions, ginger, microbial inoculants, yield

\section{Introduction}

Ginger is one of the major spice crops of Kerala and is used as a fresh vegetable and dried spice, since time immemorial. Several factors viz., environmental degradation, loss of ecosystem components, climate change, pest and disease incidence hinder the production and the major one is its susceptibility to various diseases. This has led to the use of a heavy dose of fungicides and antibiotics for the management of biotic stress. Ginger is also a highly nutrient- 
depleting crop, which demands the use of high doses of organic manure and chemical fertilizers. Although chemical fertilizers and pesticides are highly effective, their continuous use has led to many environmental problems. Increased use of inorganic fertilizers has created environmental issues such as air pollution, reduced biodiversity, suppressed ecosystem function, and deterioration of soil and ground water quality. Moreover, indiscriminate use of agrochemicals for the control of pathogens is causing serious ecological, economic, and social problems. Alternative approaches are therefore needed to minimize the use of chemical fertilizers, fungicides, antibiotics and insecticides, since ginger is directly consumed. Dutta et al. (2003) reported that the use of organic fertilizers together with chemical fertilizers showed positive effect on microbial biomass and soil health. Therefore, emphasis should be given to the organic cultivation of ginger by minimizing chemical fertilizers and pesticides. Microbial inoculants are formulations of beneficial microorganisms used to promote plant growth and manage plant diseases.

The quantum of plant growth-promoting activities is better in consortia or mixed cultures than a single strain (Bashan et al. 2004). Sarma \& Anandaraj (1998) suggested the consortium approach for disease management in plantation and spice crops. Sarma et al. (2000) have established the biocontrol consortium for black pepper, ginger, and cardamom. Introduction of nitrogen fixers, phosphate solubilizing bacteria (PSB), and potash solubilizing bacteria along with biocontrol agents will not only supply the primary nutrients to the plants but also manage the diseases with multiple actions. The treatments with biofertilizers improved the rhizome quality by increasing the oleoresin content in the rhizome. Azotobacter not only fixed $\mathrm{N}$, but also produced antifungal antibodies which inhibited the growth of several pathogenic fungi in the root region and hence improved root growth and crop nutrition which improved the quality of the product (Subba Rao 2001). N10 (Pantoea, sp.) and SJN5 (Arthrobacter) showed biocontrol efficacy and reduced disease incidence by $39.98 \%$ and $45.61 \%$, respectively. Moreover, N10 and SJN5 promoted root length by $25.5 \%$ and $26.6 \%$ shoot dry weight by $12.5 \%$ and $20.1 \%$ and root dry weight by $15.4 \%$ and $17.9 \%$, respectively. Therefore, a single formulation consisting of both biofertilizer and biocontrol agents would be an ideal technology for plant growth promotion and disease management in the present-day agriculture. Hence, a study was undertaken to evaluate the bioinoculant consortia for organic cultivation of ginger and identify a consortium for plant growth promotion and disease management in ginger under field condition.

\section{Materials and methods}

\section{Collection of microbial strains}

The efficient cultures of microbial inoculants viz., Azospirillum lipoferum, Bacillus megaterium (PSB), Bacillus sporothermodurans (KSB), P. fluorescens, and T. viride of KAU were obtained from the repository of the Department of Agricultural Microbiology, College of Agriculture, Vellayani, Thiruvanthapuram. The media used for the maintenance of isolates were Okon's nitrogen-free media for A. lipoferum, Pikovskaya's agar for $B$. megaterium, Glucose Yeast Calcium agar media for B. sporothermodurans, King's B agar for $P$. fluorescens and potato dextrose agar for T. viride.

\section{Compatability studies among the microbial cultures}

The compatibility among the bacterial isolates was tested by the cross streak method using nutrient agar media (Raja et al. 2006), and compatibility between bacteria and fungus was studied by dual culture technique (Morton \& Strouble, 1955) using potato dextrose agar media. The carrier-based inoculants were prepared by blending vermicompost with the respective culture broth (Zaidi et al 2014) and it was applied to the soil. The population of bacteria was maintained at $10^{8} \mathrm{cfu} \mathrm{ml}^{-1}$ and $10^{6}$ cfu $\mathrm{ml}^{-1}$ in case of fungus. 
Field evaluation of microbial inoculant consortia for plant growth promotion and disease management

The experiment was conducted at the College of Agriculture, Vellanikkara, Kerala Agricultural University. The plot was located at 10.550708 latitude, 76.27398 longitude and $31.0 \mathrm{~m}$ MSL elevation. The initial soil physiocochemical parameters were as follows: Soil $\mathrm{pH}$ : 5.6, organic carbon: $1.4 \%$, available nitrogen: 230.3 $\mathrm{kg} \mathrm{ha}^{-1}$., available phosphorus: $50.13 \mathrm{~kg} \mathrm{ha}^{-1}$ and available potassium: $203.1 \mathrm{~kg} \mathrm{ha}^{-1}$. The ginger plants were maintained in a randomized complete block design (RCBD) and 'Himachal' variety was used as it has less fibre and gives good quality gingerol for oleoresin production.

The incidence of rhizome rot was estimated in each field following the formula: (Number of diseased plants / Total number of plants x 100) (Sagar et al. 2008). The characteristic initial symptom of rhizome rot appearance was yellowing of leaves and in the early stages, a few tillers showed symptom of yellowing. The leaves showed drooping, withering and drying. The infected shoot could be easily pulled out from the soil. The rhizome showed water-soaked and mushy appearance. Per cent disease incidence of Rhizoctonia leaf blight was estimated as per Chiang (2017): Per cent disease incidence $=($ Number of diseased leaves/ Total number of leaves) $\times 100$. In the case of Rhizoctonia leaf blight, the lesions were usually observed on the leaf sheaths although leaf blades also get affected. Initially, lesions were small, ellipsoid or ovoid, and greenishgray. Under favorable conditions, they enlarge and may coalesce to form bigger lesions with irregular outline.

A bed of size $2 \times 1 \mathrm{~m}^{2}$ with a spacing of $25 \times 25$ $\mathrm{cm}$ was adopted. The treatments applied were as follows:

$\mathrm{T}_{1}$ : Azospirillum lipoferum

$\mathrm{T}_{2}$ : Bacillus megaterium

$\mathrm{T}_{3}$ : Bacillus sporothermodurans

$\mathrm{T}_{4}$ : Pseudomonas fluorescens
$\mathrm{T}_{5}$ : Trichoderma viride

$\mathrm{T}_{6}$ : Azospirillum lipoferum + Bacillus megaterium + Bacillus sporothermodurans

$\mathrm{T}_{7}$ : Azospirillum lipoferum + Bacillus megaterium + Bacillus sporothermodurans + Pseudomonas fluorescens

$\mathrm{T}_{8}$ : Azospirillum lipoferum + Bacillus megaterium + Bacillus sporothermodurans + Trichoderma viride

$\mathrm{T}_{9}$ :Organic Adhoc package (KAU, 2009)

$\mathrm{T}_{10}$ : Control

Before planting, the seed rhizomes were soaked in a solution containing Pseudomonas fluorescens @ $20 \mathrm{~g} \mathrm{l}^{-1}$ for $30 \mathrm{~min}$ and dried under shade. FYM / compost was applied @ $25 \mathrm{t}$ as basal and $3 \mathrm{t} \mathrm{ha}^{-1}$ each at 60 days after planting and 120 days after planting. FYM, Trichoderma, neem cake mixture@100 g plant $\mathrm{t}^{-1}$ were applied in the planting pit at the time of planting. Azospirillum was applied@ $2.5 \mathrm{~kg} \mathrm{ha}^{-1}$. The same dose was repeated at 120 days after planting.

Farmyard manure was applied in all the treatments@30 t ha-1 . Treatments $\mathrm{T}_{1}$ to $\mathrm{T}_{8}$

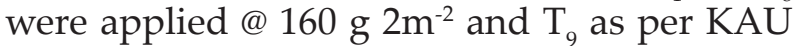
POP (2011) recommendation. Observations on the number of days taken for germination, germination percentage, number of tillers, plant height, rhizome yield, and disease incidence were recorded. The data were analyzed using the statistical package MSTAT-C (Freed 1986) and Duncan's Multiple Range Test (Duncan 1955).

\section{Results and discussion}

Microbial consortia can consist of two or more strains that are either closely or distantly related (Ramírez-López et al. 2019; ElMaaloum et al. 2020) that provide an overall additive or synergistic effect. In the present studies the different isolates of KAU-AZO, KAUPSB, KAU-KSB, KAU-PF, and KAU-TV were subjected to a compatibility test. It was observed that all the bacterial cultures tested were mutually compatible with each other (Fig 1). Fitriatin \& Nurmala (2019) reported that 
P-solubilizers such as Pseudomonas mallei, $P$. cepaceae, Aspergillus niger, Penicillium sp., and N fixing bacteria namely Azotobacter chroococum, Azospirillum sp. were synergistic and did not antagonist to each other and hence, consortia of P-solubilizers and $\mathrm{N}$-fixing bacteria can be used for agricultural purposes. In a similar study, Raja et al. (2006) reported compatibility of A. lipoferum, B. megaterium var phosphaticum, and $P$. fluorescens among each other. Khorshidi (2011) also reported that $P$. fluorescens and $A$. lipoferum were compatible with each other which are in agreement with present results. KAU-TV and KAU-PF were incompatible with each other (Fig 2). It contradicts Manjula et al. (2004) findings, who reported in vitro compatibility of $P$. fluorescens and Trichoderma sp. in dual culture and found that $P$. fluorescens did not affect the growth of Trichoderma sp. or vice versa. In the present study, KAUPF and KAU-TV were incompatible which might be attributed to the action of organic volatiles produced by KAU-PF that might have inhibited the mycelial growth of the fungus. The consortium KAU-AZO + KAU-PSB+KAUKSB showed their compatibility with KAU-TV. The compatibility of $T$. viride with Azospirillum under in vitro has already been reported (Sankar and Jayarajan, 1996) which is in agreement with the present studies.

Based on the compatibility studies, the consortia consisting of biofertilizers alone and biofertilizer cum biocontrol agents were selected for the field evaluation. Consortia including biocontrol agents KAU-PF and

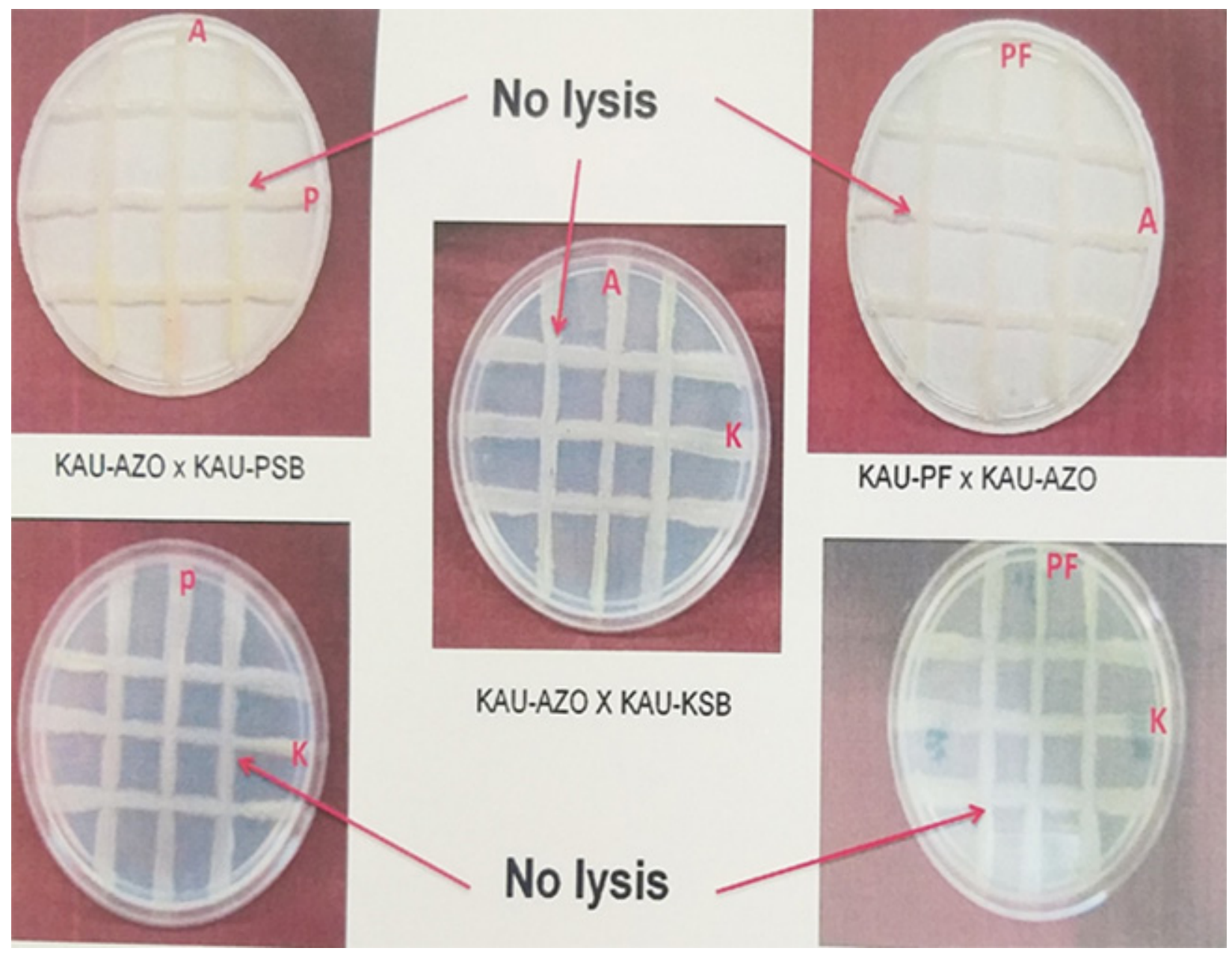

Fig 1. In vitro evaluation of compatability between bacteria and bacteria 


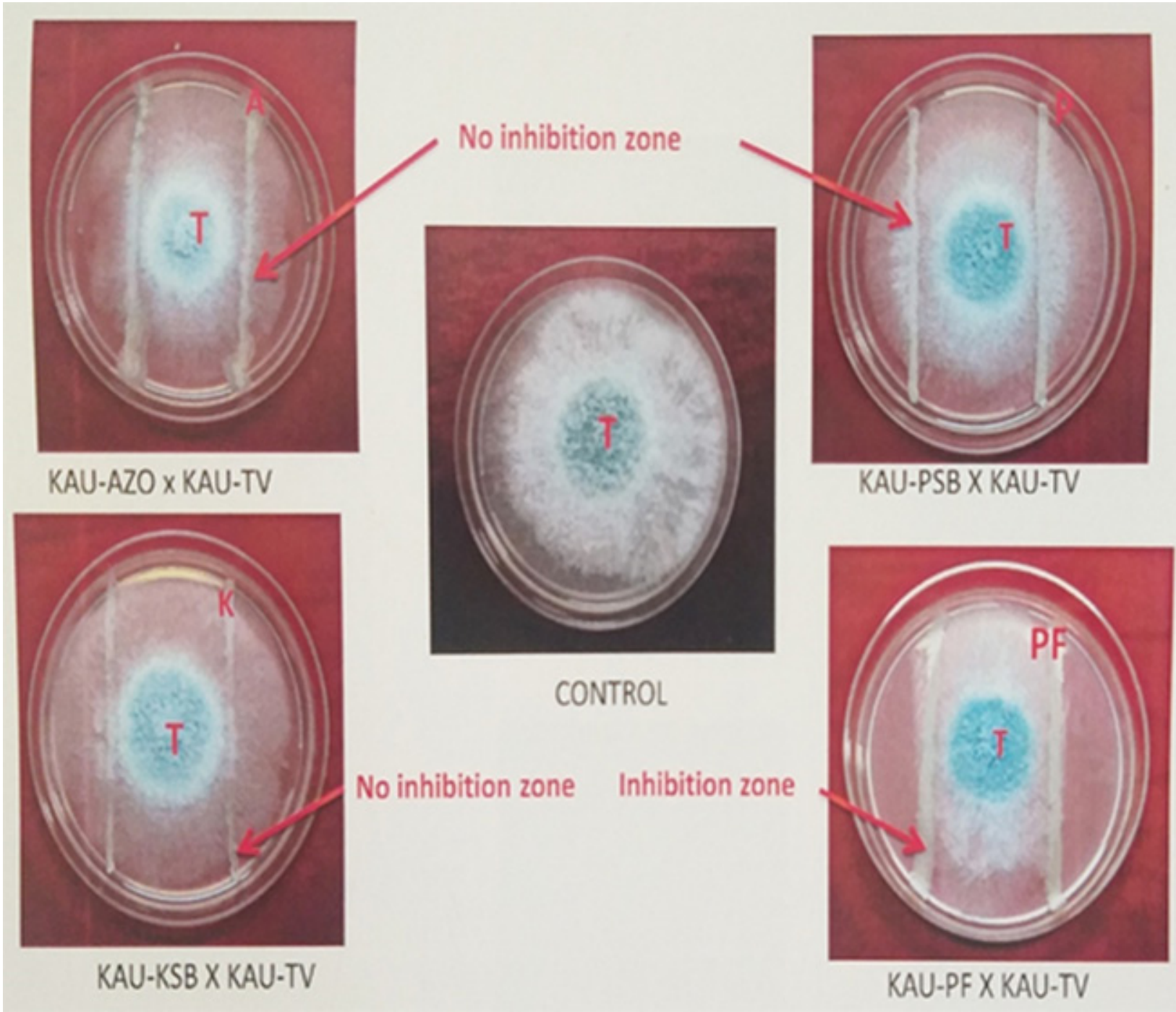

Fig 2. In vitro evaluation of compatability between bacteria and Trichoderma viride

KAU-TV were not selected for further studies as both were incompatible with each other. The consortia selected were KAU-AZO +KAU- PSB + KAU-KSB, KAU-AZO + KAU-PSB + KAUKSB + KAU-PF and KAU-AZO + KAU-PSB + KAU-KSB + KAU-TV.

The effect of biofertilizers alone and its consortia were evaluated under field conditions using ginger crop. The number of days taken for sprouting ranged between 1620 days for different treatments. However, no significant differences were observed among the treatments in number of days taken for sprouting. The minimum number of days (16.67) was recorded in the case of KAU-PF.
Selvakumar (2009) reported Pseudomonas and Bacillus can produce phytohormones like indole acetic acid (IAA) and gibberellic acid (GA3) that increases uptake of water and nutrients, per cent germination and rate of germination, plant biomass and nutrient uptake. Among the consortia, both KAUAZO + KAU-PSB + KAU-KSB + KAU-PF and KAU-AZO + KAU-PSB + KAU-KSB + KAU-TV recorded the highest germination (91.67\%). The increase in germination percentage after five days of consortial inoculation in the soil might be due to the production of indole acetic acid. The highest plant height was recorded in the case of plants inoculated with organic adhoc package (KAU 2009) (32.7\% over control) 
followed by KAU-AZO + KAU-PSB + KAUKSB + KAU-TV (20.5\% increase over control) and KAU-AZO + KAU-PSB + KAU-KSB + KAU-PF (20.4\% increase over control) and the consortia treated plants performed better than individual inoculants (Table 1). Among the consortia, the plant height was highest (74.86 $\mathrm{cm})$ in the case of KAU-AZO + KAU-PSB + KAU-KSB + KAU-TV (20.5\% increase over control). This might be due to the optimum supply of nutrients from organic sources. Microbial inoculants might have helped in the better uptake of nutrients, more synthesis of nucleic and amino acids, amide substances and formation of meristematic tissues thereby increased the growth of plants which is in agreement with the findings of Saxena et al. (2001) in soybean.
The maximum numbers of tillers were recorded in the treatment KAU-AZO + KAU-PSB + KAUKSB + KAU-TV (Table 2). Sumathi et al. (2011) reported that co-inoculation of $A$. lipoferum, $T$. viride, B. megaterium, $P$. fluorescens resulted in maximum plant height in turmeric. Similarly, Nath and Korla (2000) reported higher tiller and leaf production per plant in ginger due to the influence of biofertilizers which support the positive effect of biofertilizer in the present study.

Among the consortia based treatments, maximum rhizome yield per bed $(57.6 \%$ increase over control) was observed in KAU-AZO + KAU-PSB + KAU-KSB + KAU-TV (Table 3) followed by KAU-AZO + KAU-PSB + KAU-KSB + KAU-PF (55.5\% increase over control). This

Table 1. Effect of consortia and individual bioinoculant on plant height $(\mathrm{cm})$

\begin{tabular}{|c|c|c|c|c|c|c|}
\hline \multirow[t]{3}{*}{ Treatment } & \multicolumn{5}{|c|}{ Plant height $(\mathrm{cm})$} & \multirow{3}{*}{$\begin{array}{c}\text { Per cent } \\
\text { increase over } \\
\text { control }\end{array}$} \\
\hline & \multicolumn{5}{|c|}{ Months after planting } & \\
\hline & 1 & 2 & 3 & 4 & 5 & \\
\hline $\mathrm{T}_{1}: \mathrm{KAU}-\mathrm{AZO}$ & $14.96^{\mathrm{bc}}$ & $27.61^{e}$ & $36.04^{f}$ & $59.74 \mathrm{bcd}$ & $72.23 \mathrm{~cd}$ & 16.2 \\
\hline $\mathrm{T}_{2}:$ KAU-PSB & $13.37^{c}$ & $26.23^{\text {ef }}$ & $35.71^{f}$ & $55.61^{\mathrm{de}}$ & $71.13^{\mathrm{de}}$ & 14.5 \\
\hline $\mathrm{T}_{3}:$ KAU-KSB & $15.24^{\mathrm{bc}}$ & $23.233^{f}$ & $32.54^{g}$ & $50.21^{\mathrm{ef}}$ & $65.67^{\text {ef }}$ & 5.7 \\
\hline $\mathrm{T}_{4}: \mathrm{KAU}-\mathrm{PF}$ & $16.14^{\mathrm{abc}}$ & $28.68^{\mathrm{de}}$ & $37.5^{\mathrm{ef}}$ & $59.08^{\mathrm{cd}}$ & $72.73^{\text {cd }}$ & 17.0 \\
\hline $\mathrm{T}_{5}: \mathrm{KAU}-\mathrm{TV}$ & $16.68^{\mathrm{abc}}$ & $31.72 \mathrm{~cd}$ & $39.42^{\mathrm{e}}$ & $60.95^{\mathrm{bcd}}$ & $73.78^{\mathrm{bcd}}$ & 18.7 \\
\hline $\begin{aligned} \mathrm{T}_{6}: & \mathrm{KAU}-\mathrm{AZO}+\mathrm{KAU}- \\
& \mathrm{PSB}+\mathrm{KAU}-\mathrm{KSB}\end{aligned}$ & $18.15^{\mathrm{ab}}$ & $32.16^{\mathrm{bcd}}$ & $39.34^{\mathrm{e}}$ & $61.03^{\mathrm{bcd}}$ & $73.55 \mathrm{bcd}$ & 18.4 \\
\hline $\begin{aligned} \mathrm{T}_{7}: & \mathrm{KAU}-\mathrm{AZO}+\mathrm{KAU}- \\
& \mathrm{PSB}+\mathrm{KAU}-\mathrm{KSB}+ \\
& \mathrm{KAU}-\mathrm{PF}\end{aligned}$ & $17.62^{\mathrm{ab}}$ & $33.56^{a b c}$ & $39.72^{\mathrm{e}}$ & $61.94^{\mathrm{bc}}$ & $74.80^{\mathrm{bcd}}$ & 20.4 \\
\hline $\begin{aligned} \mathrm{T}_{8}: & \mathrm{KAU}-\mathrm{AZO}+\mathrm{KAU}- \\
& \mathrm{PSB}+\mathrm{KAU}-\mathrm{KSB}+ \\
& \mathrm{KAU}-\mathrm{TV}\end{aligned}$ & $18.21^{\mathrm{ab}}$ & $35.65^{\mathrm{ab}}$ & $43.08^{d}$ & $62.03^{\mathrm{bc}}$ & 74.86 bcd & 20.5 \\
\hline $\begin{array}{l}\mathrm{T}_{9}: \text { Organic adhoc } \\
\text { package (KAU, } \\
\text { 2009) }\end{array}$ & $18.80^{\mathrm{ab}}$ & $37.04^{\mathrm{a}}$ & $51.15^{\mathrm{a}}$ & $68.17^{a}$ & $82.45^{\mathrm{a}}$ & 32.7 \\
\hline $\mathrm{T}_{10}$ : Control & $13.51^{\mathrm{c}}$ & $22.97^{f}$ & $31.57^{\mathrm{g}}$ & $48.09^{\mathrm{f}}$ & $62.15^{\mathrm{f}}$ & 0 \\
\hline $\mathrm{CD}(0.05)$ & 4.08 & 3.78 & 2.57 & 5.99 & 6.33 & \\
\hline
\end{tabular}

Values are mean of 32 rhizomes planted in 3 beds per season

KAU-AZO : Azospirillum lipoferum

KAU-PF : Pseudomonas fluorescens

KAU-PSB : $\quad$ Bacillus megaterium

KAU-TV : $\quad$ Trichoderma viride

KAU-KSB : Bacillus sporothermodurans 
Table 2. Effect of consortia and individual bio inoculants on number of tillers

\begin{tabular}{lccc}
\hline Treatment & \multicolumn{3}{c}{ Months after planting } \\
\cline { 2 - 4 } & $2^{*}$ & 4 & 6 \\
\hline $\mathrm{T}_{1}:$ KAU-AZO & 1.52 & $6.21^{\text {bcd }}$ & $6.33^{\text {cde }}$ \\
$\mathrm{T}_{2}:$ KAU-PSB & 1.50 & $5.67^{\text {cd }}$ & $6.09^{\text {de }}$ \\
$\mathrm{T}_{3}:$ KAU-KSB & 1.56 & $5.38^{\mathrm{d}}$ & $5.89^{\text {ef }}$ \\
$\mathrm{T}_{4}:$ KAU-PF & 1.55 & $5.81^{\text {bcd }}$ & $5.92^{\text {ef }}$ \\
$\mathrm{T}_{5}:$ KAU-TV & 1.53 & $6.25^{\text {bd }}$ & $6.70^{\text {cde }}$ \\
$\mathrm{T}_{6}:$ KAU-AZO + KAU-PSB + KAU-KSB & 1.72 & $6.23^{\text {bd }}$ & $6.87^{\text {cd }}$ \\
$\mathrm{T}_{7}:$ KAU-AZO + KAU-PSB + KAU-KSB + KAU-PF & 1.78 & $6.53^{\text {abcd }}$ & $6.94^{\text {bcd }}$ \\
$\mathrm{T}_{8}:$ KAU-AZO + KAU-PSB + KAU-KSB + KAU-TV & 1.81 & $6.72^{\text {abcd }}$ & $7.06^{\text {bc }}$ \\
$\mathrm{T}_{9}:$ Organic adhoc package (KAU, 2009) & 1.78 & $7.93^{\mathrm{a}}$ & $8.14^{\mathrm{a}}$ \\
$\mathrm{T}_{10}:$ Control & 1.41 & $5.33^{\mathrm{d}}$ & $5.18^{\mathrm{f}}$ \\
CD (0.05) & $\mathrm{NS}$ & 1.43 & 0.79 \\
\hline
\end{tabular}

Values are mean of 32 rhizomes planted in 3 beds per season

* No significant difference

KAU-AZO: Azospirillum lipoferum

KAU-PF : Pseudomonas fluorescens

KAU-PSB : Bacillus megaterium

KAU-TV : Trichoderma viride

KAU-KSB : Bacillus sporothermodurans

Table 3. Effect of consortia and individual bio inoculants on rhizome yield

\begin{tabular}{lcc}
\hline Treatment & Yield $\left(\mathrm{kg} \mathrm{2 \textrm {m } ^ { 2 } )}\right.$ & $\begin{array}{c}\text { Percent increase over } \\
\text { control }\end{array}$ \\
\hline $\mathrm{T}_{1}:$ KAU-AZO & 3.08 & 30.5 \\
$\mathrm{~T}_{2}:$ KAU-PSB & 2.70 & 14.4 \\
$\mathrm{~T}_{3}:$ KAU-KSB & 2.40 & 1.7 \\
$\mathrm{~T}_{4}:$ KAU-PF & 2.86 & 21.2 \\
$\mathrm{~T}_{5}:$ KAU-TV & 3.18 & 34.7 \\
$\mathrm{~T}_{6}:$ KAU-AZO + KAU-PSB + KAU-KSB & 3.43 & 45.3 \\
$\mathrm{~T}_{7}:$ KAU-AZO + KAU-PSB + KAU-KSB + KAU-PF & 3.67 & 55.5 \\
$\mathrm{~T}_{8}:$ KAU-AZO + KAU-PSB + KAU-KSB + KAU-TV & 3.72 & 57.6 \\
$\mathrm{~T}_{9}:$ Organic Adhoc package (KAU, 2009) & 4.59 & 94.5 \\
$\mathrm{~T}_{10}:$ Control & 2.36 & 0 \\
CD (0.05) & 1.56 & \\
\hline
\end{tabular}

Values are mean of 32 rhizomes planted in 3 beds per season

KAU-AZO : Azospirillum lipoferum.

KAU-PF : Pseudomonas fluorescens

KAU-PSB : Bacillus megaterium

KAU-TV : Trichoderma viride

KAU-KSB : Bacillus sporothermodurans 
might be due to the optimum supply of nutrients from organic sources and bioinoculants which increased the plant growth. Chandrashekhar and Hore (2019) reported maximum number of primary fingers (3.84), weight of primary fingers $(45.67 \mathrm{~g})$, length of primary fingers $(4.36 \mathrm{~cm})$, length of secondary fingers $(9.09 \mathrm{~cm})$, breadth of secondary fingers $(6.61 \mathrm{~cm})$, rhizome yield $(26.43$ $\mathrm{t} \mathrm{ha}^{-1}$ ) and oleoresin (6.86) content in ginger in NPK 100\% + Azotobacter + PSB + K mobilizer. Asokan et al. (2002) and Sreekala (2004) reported increased yield in ginger due to the addition of farmyard manure and biofertilizers which improved soil fertility. Based on the overall biometric and yield parameters, KAU-AZO + KAU-PSB + KAU-KSB + KAU-TV performed better among the consortia in the present study. However, Organic Adhoc package (KAU 2009) performed better than the consortia treatments.

One of the major constraints in ginger cultivation is the disease incidence. In the present study, diseases observed were rhizome rot caused by Pythium sp. and Rhizoctonia leaf blight by Rhizoctonia solani (Table 4). The treatment (Organic Adhoc package) recorded a minimum incidence of rhizome rot $(2.09 \%)$ among all the treatments. However, KAU-AZO + KAU-PSB + KAU-KSB + KAU-TV recorded the minimum rhizome rot incidence $(5.23 \%)$ among the consortia under study. Tripathi \& Singh (2021) reported that ginger rhizome

Table 4. Effect of consortia and individual bio inoculants on percent incidence of rhizome rot and Rhizoctonia leaf blight

\begin{tabular}{|c|c|c|c|c|c|c|}
\hline \multirow[t]{3}{*}{ Treatment } & \multicolumn{6}{|c|}{ Percent incidence } \\
\hline & \multicolumn{3}{|c|}{ Rhizome rot } & \multicolumn{3}{|c|}{ Rhizoctonia leaf blight } \\
\hline & $3 \mathrm{MAP}$ & $4 \mathrm{MAP}$ & $5 \mathrm{MAP}$ & $3 \mathrm{MAP}$ & $4 \mathrm{MAP}$ & $5 \mathrm{MAP}$ \\
\hline $\mathrm{T}_{1}: \mathrm{KAU}-\mathrm{AZO}$ & $5.21^{\mathrm{a}}(2.37)$ & $5.23^{\mathrm{a}}(2.37)$ & $8.37^{\mathrm{abc}}(2.97)$ & $4.17(2.14)$ & $5.21(2.15)$ & $7.29(2.73)$ \\
\hline $\mathrm{T}_{2}:$ KAU-PSB & $4.17^{\mathrm{ab}}(2.14)$ & $5.23^{\mathrm{a}}(2.27)$ & $8.37^{\mathrm{abc}}(2.97)$ & $4.17(2.14)$ & $8.35(2.94)$ & $10.43(3.27)$ \\
\hline $\mathrm{T}_{3}:$ KAU-KSB & $5.21^{\mathrm{a}}(2.15)$ & $5.23^{\mathrm{a}}(2.37)$ & $7.33^{\mathrm{a}}(3.3)$ & $4.17(2.14)$ & $8.35(2.89)$ & $9.39(3.12)$ \\
\hline $\mathrm{T}_{4}: \mathrm{KAU}-\mathrm{PF}$ & $2.78^{\mathrm{abc}}(1.87)$ & $3.14^{\mathrm{abc}}(1.91)$ & $6.28^{\mathrm{abc}}(2.6)$ & $1.04(1.92)$ & $4.17(1.92)$ & $5.18(2.5)$ \\
\hline $\mathrm{T}_{5}: \mathrm{KAU}-\mathrm{TV}$ & $0.00^{c} \quad(0.7)$ & $1.04^{\mathrm{c}}(1.12)$ & $6.28^{\mathrm{abc}}(2.55)$ & $2.08(1.51)$ & $6.26(2.6)$ & $6.26(2.6)$ \\
\hline $\begin{aligned} \mathrm{T}_{6}: & \mathrm{KAU}-\mathrm{AZO}+\mathrm{KAU}- \\
& \mathrm{PSB}+\mathrm{KAU}-\mathrm{KSB}\end{aligned}$ & $2.7^{\mathrm{abc}}(1)$. & $4.19^{\mathrm{ab}}(2.4)$ & $7.33^{\mathrm{abc}}(2.7)$ & $3.13(1.4)$ & $7.30(2.71)$ & $9.39(3.04)$ \\
\hline $\begin{aligned} & \mathrm{T}_{7}: \mathrm{KAU}-\mathrm{AZO}+\mathrm{KAU}- \\
& \mathrm{PSB}+\mathrm{KAU}-\mathrm{KSB}+ \\
& \mathrm{KAU}-\mathrm{PF}\end{aligned}$ & $4.17^{\mathrm{ab}}(2.14)$ & $5.23^{\mathrm{a}}(2.3)$ & $6.28^{\mathrm{abc}}(2.5)$ & $2.08(1.1)$ & $4.17(2.14)$ & $5.21(2.37)$ \\
\hline $\begin{aligned} \mathrm{T}_{8}: & \mathrm{KAU}-\mathrm{AZO}+\mathrm{KAU}- \\
& \mathrm{PSB}+\mathrm{KAU}-\mathrm{KSB}+ \\
& \mathrm{KAU}-\mathrm{TV}\end{aligned}$ & $3.13^{\mathrm{ab}}(1.91)$ & $3.14^{\mathrm{abc}}(1.91)$ & $5.23^{\mathrm{a}}(2.37)$ & $5.21(2.15)$ & $6.26(2.55)$ & $6.26(2.55)$ \\
\hline $\begin{array}{c}\mathrm{T}_{9} \text { : Organic adhoc } \\
\text { package (KAU, } \\
\text { 2009) }\end{array}$ & $0.00^{c}(0.7)$ & $1.04^{c}(1.12)$ & $2.09^{d}(1.51)$ & $1.04(1.11)$ & $3.13(1.74)$ & $4.17(1.97)$ \\
\hline $\mathrm{T}_{10}$ : Control & $6.25^{\mathrm{a}}(2.55)$ & $6.28^{\mathrm{a}}(2.6)$ & $9.42^{\mathrm{ab}}(3.12)$ & $7.30(2.71)$ & $9.39(3.12)$ & $12.51(3.59)$ \\
\hline $\mathrm{CD}(0.05)$ & 3.7 & 2.9 & 4.23 & NS & NS & NS \\
\hline
\end{tabular}

Values are mean of 32 rhizomes planted in 3 beds per season

MAP: $\quad$ Months after planting

Figures in parenthesis are square root transformed values

KAU-AZO : Azospirillum lipoferum.

KAU-PF : Pseudomonas fluorescens

KAU-PSB : Bacillus megaterium

KAU-TV : Trichoderma viride.

KAU-KSB : Bacillus sporothermodurans 
treatment by copper hydroxide and its soil drenching effectively controlled rhizome rot disease $(67 \%)$ with reduced disease incidence (4.6\%) followed by $T$. viride which controlled the disease by $53.5 \%$ and reduced the disease incidence by $6.8 \%$ (over local check) which are in agreement with the present study where the T. viride in combination with NPK biofertilizers could effectively control the disease in ginger. Gupta et al. (2010) also reported the effectiveness of Trichoderma spp. against many fungal diseases particularly rhizome pathogens. Trichoderma strains establish long-lasting colonization of plant roots and penetrate the epidermis and produce or release compounds that induce localized or systemic plant resistance responses (Harman 2004). In a similar study, it was reported that rhizome treated with the Trichoderma sp. significantly reduced rhizome rot incidence and also increased the yield (Ram et al. 2000). T. viride produced non-volatile substances that inhibited the growth of the ginger rhizome rot pathogens viz. P. myriotylum and F. solani (Rathore et al. 1992). These results are in accordance with the present studies. However, the incidence of leaf blight was the lowest in the Organic Adhoc package at 4.17\%.

The ginger plants treated with consortia $\mathrm{AZO}+$ KAU-PSB + KAU-KSB + KAU-PF also recorded the minimum incidence $(5.21 \%)$ of Rhizoctonia leaf blight among the consortia. The incidence of the disease was lowest $(15.63 \%)$ in seed treatment (TD) and soil application of $P$. fluorescens and $T$. harzianum consortia mass cultured in the mixture of vermicompost and mustard oil cake (Bora et.al. 2016), P. fluorescens is known to exhibit strong antifungal activity mainly through the production of antifungal metabolites. Nandakumar et al. (2001) reported two P. fluorescens strains, (PF1 and FP7) which inhibited the mycelia growth of sheath blight fungus $R$. solani and increased the seedling vigor of rice plants and yield. Biofertilizers improve soil health and provide protection against drought and some soil-borne diseases (Ellafi et al. 2010). In the present study, it was found that KAU-PF was more effective in the management of leaf diseases, whereas consortia with $T$. viride were effective in the control of rhizome rot incidence.

As ginger is highly amenable to organic inputs, organic cultivation of ginger must be encouraged as the ginger is directly consumed. The present study indicated that ginger plants inoculated with microbial inoculants consortia performed better than the individual microbial inoculants. The consortia of microbial inoculants treated plants were on par based on most of the parameters, but $\mathrm{T}_{8} \mathrm{KAU}-\mathrm{AZO}$ + KAU-PSB + KAU-KSB + KAU-TV performed better among the consortia used.

\section{References}

Asokan R, Mohandas S \& Anand L 2002 Biofertilizer and biopesticides for horticultural crops. Indian Hortic. pp.44-47.

Bashan Y, Holguin G \& De-Bashan L 2004 Azospirillum-plant relationships: physiological, molecular, agricultural, and environmental advances (1997-2003). Canadian J. Microbiol. 50: 521-577.

Bora P, Bora L C, Deka P C, Bikram Borotoki A K, Sharma H S, Dutta \& Debahaj Buhagohain 2016 Efficacy of Pseudomonas fluorescens and Trichoderma viride based bioformulation for management of bacterial wilt disease of ginger. Int. J. Plant Sci. 11: 180-186.

Chandrashekhara G \& Hore J K 2019 Yield and quality of ginger as influenced by biofertilizers, organic and inorganic manures. Int. J. Curr. Microbiol. App. Sci. 8: 968-972.

Chiang K S, Liu H I \& Bock C H 2017 A discussion on disease severity index values. Part I: Warning on inherent errors and suggestions to maximise accuracy. Annals Applied Biol. 171: $139-154$.

Dutta S, Pal R, Chakraborty A \& Chakrabarti K 2003 Influence of integrated plant nutrient phosphorus and sugarcane and sugar yields. Field Crop Res. 77: 43-49.

Ellafi A M, Gadalla A \& Galal Y G M 2010 Biofertilizers in action: contributions of BNF in sustainable agricultural ecosystems. 
Int. Sci. Res. J. 3: 108.

El Maaloum S, Elabed A, Alaoui-Talibi Z, El Meddich A, Filali-Maltouf A \& Douira A 2020 Effect of arbuscular mycorrhizal fungi and phosphate-solubilizing bacteria consortia associated with phosphocompost on phosphorus solubilization and growth of tomato seedlings (Solanum lycopersicum L.). Commun. Soil Sci. Plant Anal. 51: 622-634. doi: 10.1080/00103624.2020.172937

Fitriatin B N \& Nurmala 2019 In vitro test for compatibility of biofertilizers containing phosphate solubilizers and nitrogen-fixing bacteria. International Seminar and Congress of Indonesian Soil Science Society 2019. IOP Conf. Series: Earth and Environmental Science 393 (2019) 012049 IOP Publishing doi:10.1088/1755-1315/393/1/012049

Gupta M, Dohroo N P, Gangta V \& Shanmugam V 2010 Effect of microbial inoculants on rhizome disease and growth parameters of ginger. Indian_Phytopath. 63: 438-441.

Khorshidi Y R \& Ardakani M R 2011 The response of yield and yield components of rice (Oryza sativa L.) to Pseudomonas fluorescens and Azospirillum lipoferum under different nitrogen levels. J.Agric. Environ. Sci. 10: 387395

Manjula K, Kishore G K, Girish A G \& Singh S D 2004 Combined application of Pseudomonas fluorescens and Trichoderma viride has an improved biocontrol activity against stem rot in groundnut. Plant Pathol. J. 20: 75-80.

Nandakumar R, Babu S, Viswanathan, R, Raguchander T \& Samiyappan R 2001 Induction of systemic resistance in rice against sheath blight disease by Pseudomonas fluorescens. Soil Biol. Biochem. 33: 603-612.

Nath B \& Korla B N 2000. Studies on the effect of biofertilizers in ginger. Indian J. Hortic. 57: 168-171.

Raja P, Uma S, Gopal H \& Govindarajan K 2006 Impact of bio inoculants consortium on rice exudates- Biological nitrogen fixation and plant growth. J.Biol. Sci. 6: 815-823.

Ram D, Mathur K, Lodha B C \& Webster J 2000 Evaluation of resident biocontrol agents as seed treatments against ginger rhizome rot.
Indian Phytopathol. 53: 450-454.

Ramírez-López C, Esparza-García F J, FerreraCerrato R, Alarcón A \& CañizaresVillanueva R O 2019 Short-term effects of a photosynthetic microbial consortium and nitrogen fertilization on soil chemical properties, growth, and yield of wheat under greenhouse conditions. J. Appl. Phycol. 31.3617-3624. doi: 10.1007/s10811-019-018612

Rathore V R S, Mathur K \& Lodha V C 1992 The activity of volatile and non-volatile substances produced by Trichoderma viride on ginger rhizome rot pathogens. Indian Phytopathol. 45: 253-254.

Rivett D W, Jones M L, Ramoneda J, Mombrikotb S B, Ransome E \& Bell T 2018 Elevated success of multispecies bacterial invasions i $\mathrm{m} \mathrm{pacts}$ community composition during ecological succession. Ecol. Lett. 21. 516-524.doi: 10.1111/ele.12916

Sagar SD, Kulkarni S \& Hedge Y R 2008 Management of rhizome rot of ginger by botanicals. J. Plant Sci. 2(2): 155-158

Sankar P \& Jeyarajan R 1996 Compatibility of antagonists with Azospirillum in sesamum. Indian Phytopathol. 49: 67-71.

Sarma Y R \& Anandaraj M 1998 Biological suppression of diseases of plantation crop and spices: present status and future strategies. pp 21-47. In: Biological Suppression of Plant Diseases, Phytoparasitic Nematodes and Weeds. Singh, S.P. and Hussaini, S.S. (eds), Project Directorate of Biological Control, Hebbal, Bangalore, Karnataka, India,

Sarma Y R, Rajan P P, Beena N, Diby P \& Anandaraj M 2000 Role of rhizobacteria on disease suppression in spice crops and prospects. In: Seminar on biological control and Plant Growth Promoting Rhizobacteria (PGPR) for sustainable agriculture, Dept. of Biosciences, School of Life Sciences, University of Hyderabad.

Saxena S C, Manral H S \& Chandel A S 2001 Effect of inorganic and organic sources of nutrients on soybean (Glycine max). Indian J. Agron. 46: 135-140.

Selvakumar G, Joshi P, Nazim S, Mishra P K, Bisht J 
K \& Gupta H S 2009 Phosphate solubilization and growth promotion by Pseudomonas fragi CS11RH1 (MTCC 8984), a psychrotolerant bacterium isolated from a high altitude Himalayan rhizosphere. Biologia. 64: 239245.

Sreekala G S 2004 Effect of organic manures and microbial inoculants on growth, yield, and quality of ginger. M.Sc. (Ag) thesis, Kerala Agricultural University, Thrissur, 242 p.

Subba R N S 2001 An appraisal of biofertilizers in India, In: S. Kannaiyan (Ed.), The Biotechnology of Biofertilizers, Narosa Publishing House, New Delhi. 45-105.

Sumathi C S, Ramesh N, Balasubramanian V \& Rajesh K V 2011 Microbial bio inoculants potential on turmeric (Curcuma longa) growth improvement under tropical nursery conditions. Asian J. Expt. Biol. Sci. 4: 612-
623.

Tosi M, Gaiero J, Linton N, Mafa-Attoye T, Castillo A \& Dunfield K 2020 b. Bacterial endophytes: diversity, functional importance, and potential for manipulation in Rhizosphere Biology: Interactions Between Microbes and Plants, eds V. V. S. R. Gupta and A. K. Sharma (Singapore), 1-49. doi: 10.1007/978-981-156125-2_1

Tripathi A K \& Singh A K 2021 Effects of Trichoderma viride and copper hydroxide on rhizome rot of ginger. Bangladesh J. Bot. 50: 45-49.

Zaidi S, Usmani S, Singh B R \& Musarrat J 2014 Significance of Bacillus subtilis strain SJ101 as a bioinoculant for concurrent plant growth promotion and nickel accumulation in Brassica juncea. Chemosphere. 64: 991-997. 